\title{
TAPodi Zsuzsa*
}

\author{
ÖNMAGUNK ÁRNYÉKÁVÁ VÁLNI. \\ CSALÁDREGÉNY A 21. SZÁZADBAN \\ GERLÓCZY MÁRTON: MIKECS ANNA: ALTATÓ
}

Kulcsszavak: Gerlóczy Márton, családregény, fiktiv narrátor, traumák, tabuk

Gerlóczy Mártonnak az általa sohasem ismert, halott nagynénje nevén 2017-ben közölt, Altató címú múve a családregény múfaji hagyományára utaló, dokumentumokon alapuló fikciónak napjainkban is népszerü prózapoétikai kánonját követő szöveg. A posztmodern eljárásokat idézi az olvasót elbizonytalanító, rendhagyó jellegü címlap, hiszen két szerzőt tüntet föl: az alkotó hagyományos helyén, a cím előtt Mikecs Anna neve szerepel, lejjebb pedig, a múfaji megjelölés mellett, a tényleges szerző neve: „Gerlóczy Márton regénye”. (A magyar irodalomban Weöres Sándor 1972-es Psyché című műve indította el a nemváltó pszeudoepigraphák sorát, amely 1987-ben Esterházy Péter Csokonai Lilijével, majd Parti Nagy Lajos Sárbogárdi Jolánjával folytatódott 1990-ben.) Maga a cím is többértelmúvé válik a szövegben, utal a sokszor felhangzó, nemzedékeken át hagyományozott gyermekcsitító versikére, de a traumák miatt pihenni nehezen tudó asszonyok által használt nyugtatókra is.

A könyv belső borítóján családfák ágrajzai láthatók, a szöveg elôtt pedig a legfőbb források feltüntetése és a belőlük vett mottók olvashatók. A hipotextusok a családi naplók, levelezések, prózai dokumentumok és lírai múvek (Áprily Lajos Annának bivták, Gyulai Pál Altató címú versei). Közös elemük, hogy a szerzőjük egy-egy kolozsvári vagy ehhez a városhoz kötődő alkotó. A regényben szereplő Jékely-Schéfer család különböző tagjainak hányódásain túl így a mű a 20. századi erdélyi magyar tágabban a minduntalan átrajzolt határú közép-kelet-európai - sorskérdéseknek is tükröt állít. A műhöz „függelékként” egy kis könyv is tartozik, amelyben a családi fényképeket nézheti meg az olvasó, miközben a könyvborító készítésének titkaiba nyer bepillantást. ${ }^{1}$ A kis könyv létrejöttének előzménye egy irodalomszociológiai szempontból is figyelemre méltó jelenség. Akárcsak másod-unokatestvére, Péterfy

TAPodi Zsuzsa dr. (1961), irodalomtörténész, Sapientia EMTE, Csíkszeredai Kar.

1 Gerlóczy Márton: Nézd csak, itt egy japán! Az Altató boritójának története. Scolar, Bp., 2018. (A továbbiakban GerLóczy: Nézd csak, itt egy japán!) 
Gergely tette a Kitömött barbár írásakor, Gerlóczy Márton is internetes blogban osztotta meg az érdeklődőkkel a hét év kutatómunkájának eredményeként összegyűjtött dokumentumokat.

A regényt bevezető mondatok Erdély irodalmának egyik markáns múfajára, az emlékiratra utalnak. „Az emlékiratokat általában az utókornak írják, a regényeket elsősorban a mának. Ez a regény családi vonatkozású naplók, levelezések, önéletrajzok, interjúk, tanulmányok, néprajzi, prózai és lírai múvek segítségével és felhasználásával készült, de vázát két nagyobb lélegzetú írás, Jékely Márta és Schéfer Ida emlékirata adja. Bár elsősorban a múltnak készült, jó szívvel ajánlom az utókornak is."2 A kánon perifériáján álló, „női” műfajok, a napló és levél megfelelnek a regény fő témájának, amelyet Jékely Zoltán - a könyv külső borítóján olvasható - szavaival „a női fájdalom szobra"-ként nevezhetünk meg.

A családregény öt generáció életébe enged betekintést, előtérben egy anya és lánya, Schéfer Ida és Jékely Márta, a szerző dédanyja és nagymamája, sorsával. A megidézett események a múlt felől haladnak a jövő felé, ám nincs közöttük kronológiai sorrend. 1946-ban kezdődik az első rész, és körülbelül 1880-tól 1980-ig zajló történések szilánkjai csapongva váltakoznak a későbbiekben. A háború utáni időszak egyrészt az újrakezdés reményével kecsegtethetett, másrészt a regény középpontjában álló Jékely Márta vonatkozásában az általa átélt veszteségek sorozata magyarázatul szolgál arra, hogy miért nem volt képes később kilépni a megalázó helyzetek tömkelegét nyújtó második házasságából. „Huszonhat éves, három élet pusztult el mellőle rövid idő alatt és közben kis híján végeztek vele is." ${ }^{3} \mathrm{Az}$ elpusztult három életről jóval később, a regény vége felé derül ki, hogy két halott gyermek és a nagyon szeretett férj, Mikecs László korai elvesztésének traumáját kellett magával hordoznia, és a felszabadítóknak hazudott katonák által elkövetett nemi erôszak emlékét is. Nemcsak a tragikus eseményekre adott pszichikus válasz miatt jellemezte a hallgatás, elhallgatás vágya a trauma elszenvedőjét. Az Erdélyből történt menekülés, kifosztás, deportálások, a szovjet katonák által elkövetett nemi erőszak, politikai okokból, makroszinten is tabunak számító témák voltak a rendszerváltozás küszöbéig. Menyhért Anna írja: „A trauma fogalmához hozzátartozik a hallgatás, pszichológiai értelemben éppúgy, mint a kulturális emlékezet vonatkozásában. A trauma elszenvedője ugyanúgy nem képes arról beszélni, amit átélt, mint ahogy a súlyos társadalmi traumákat hallgatás övezi. A traumaelmélet úgy véli, hogy a gyógyulás feltétele a történtek elmondása, az egyén és a társadalom esetében egyaránt". ${ }^{4}$

2 Gerlóczy Márton: Mikecs Anna:Altató. Scolar, Bp., 2017. 5. (A továbbiakban Gerlóczy: Altató)

3 Uo. 9.

4 Menyhért Anna: Elmondani az elmondhatatlant. Trauma és irodalom. Anonymus-Ráció, Bp., 2008. 5 . 
Jan Assmann szerint a generációs emlékezet egy-két felmenőig terjed, míg a kulturális emlékezet a távolabbi ősök tapasztalatát közvetíti. Ám az egyén szempontjából mindenképpen társadalmi környezet szükséges az emlékezet múködéséhez. „A különféle társadalmi csoportokba való beleszövődés az - a családtól a vallási és nemzeti közösségig -, ami az egyéni emlékezet kiépülését múködteti. Az emlékezet kommunikációban él és marad fönn; ha az utóbbi megszakad, illetve ha a kommunikációban közvetített valóság vonatkozási keretei változást szenvednek, vagy akár elenyésznek, a következmény: felejtés." ${ }^{5}$

Az Altató világirodalmi modelljei közül Thomas Mann $A$ Buddenbrook ház címú regényének hatása a kirajzolódó nyomvonalban érhető tetten, abban, ahogyan egy család fokozatos hanyatlása elénk tárul, Gabriel García Márquez Száz év magánya a bemutatott időintervallum és a cseppben a tenger-eljárás miatt lehetett előképe Gerlóczy regényének. A családfák ágrajza a belső borítón az olvasó tájékozódását könnyíti meg, ám a bekövetkező szakadásokat, töréseket is vizuálissá teszi. A fokozatos hanyatlás az egymást követő női generációk életlehetőségeinek beszúkülésében, az általuk megélhető harmónia idejének csökkenésében is tetten érhető. Kerekes Terézia, a nagymama egész életében boldogan töltheti be egy tisztes polgári családanya szerepét, lánya, Schéfer Ida a trianoni fordulatig 30 évet lehet boldog, míg lánya, Márta 26 éves korára már özvegy, családjától, házától és hazájától is megfosztották. Kislánya, Mikecs Anna három és fél éves korában hal meg. A lehetőségek fokozatos beszúkülését a csökkenő utódszám is jelzi: Terézia 6 gyermekkel büszkélkedhet, Idának 3, míg Mártának 2 élő utóda van. A gyermekkor idilljének és a felnőttkor kisemmizettségének ellentéte legerőteljesebben az ő sorsában érhető tetten.

Különböző családmodellekkel találkozhatunk a könyv lapjain: a kiegyensúlyozott, polgári nagycsalád, Kerekes Terézia és Schéfer András házasságának rajza az idilli állapotot jeleníti meg lányuk, Ida számára, míg a kényszerszövetség Cziegler Berta és Johann Ludvig Jekely között, melyet a férj sikkasztási ügye csak súlyosbít, negatívan befolyásolja fiuknak, a finom lelkű költônek és rajongva szeretett tanárnak, Áprily Lajosnak a viselkedését feleségével szemben. A kezdeti idill az ő esetükben ugyanúgy szertefoszlik, mint a hamarosan pokollá váló kapcsolat Jékely Márta és második férje, Mészáros Dezső közös élete esetében. A változtatás lehetősége, a kilépés a társadalmilag determinált keretek közül Márta lánya, Mészáros Zsófi sorsában sejlik fel, aki férjét, Gerlóczy Ferencet egy-kettő lecseréli Váczy Tamással, akivel megszökik az országból. „Márta biztos abban, hogy Zsófi nem lesz annyira megalkuvó, mint o, ahhoz nem szenvedett eleget, hogy kitartson megalázó, szívszorongató helyzetekben." 6

5 Jan Assmann: A kulturális emlékezet. Irás, emlékezés és politikai identitás a korai magaskultúrákban. Ford. Hidas Zoltán, Atlantisz, Bp., 1999.37.

6 Gerlóczy: Altató. 423. 
Márta tragédiája a választás lehetőségeinek a hiánya, a teljes emberi kibontakozás elgáncsolódása. „Borzalmasan fáj hallgatnia, amikor Dezső arról beszél, ezekből a diákokból mind zsenit csinál majd, miközben ő - aki valóban tehetséges volt, miatta és a családért arról a legfőbb örömről, amit a művészet, az alkotás nyújtott neki, le kellett mondania, ő, akit tulajdonképpen elnyomott, belefojtott a gyermeknevelés, a háztartás gondjaiba és megfosztott jóformán a mozgási szabadságtól is - csak háziasszonyként van jelen, holott mindegyiküknél jobban ért ahhoz, amivel ezeken a délutánokon foglalkoznak, amiről beszélnek, amiket alkotnak."7

\section{DOKUMENTUM ÉS FIKCIÓ}

Wolfgang Iser ${ }^{8}$ az irodalom hagyományos szerepeinek, a szórakoztatásnak, tájékoztatásnak és dokumentálásnak egyfajta átrendeződését konstatálja, hiszen ezek különböző, önálló, speciális intézmények hatáskörébe kerültek át, amelyek versenyre keltek az irodalommal. Ugyanakkor a megélt események művészi dokumentálásának igénye továbbra is aktuális marad.

Umberto Eco szerint egyetlen fikció sem tud teljes mértékben elszakadni a valóságtól. Annak a képnek, amely a valóságról alakul ki, két alapfeltétele van: „az egyéni és a kollektív emlékezet". ${ }^{9}$ Az egyéni emlékezet mindazon tényekre vonatkozik, melyek tapasztalati úton sajátítandók el, azaz a személyes „történelemre”. Míg a kollektív emlékezet „megmondja nekünk, mikor és hol született anyánk”, ${ }^{10}$ azaz, bizonyos írásos, rögzített dokumentáció a múltról, nevezhetjük ennek termékeit akár „mítosznak" is, melyet a korábbi generációk alakítottak. Gerlóczy Márton a kis könyvben nem csupán a családi fényképeket közli, de a külső, japán perspektíva segítségével át is értelmezi az Altató által az olvasóban kialakult összbenyomást. Az alkotáshoz szükséges helyzetismeretről, amikor elvállalta a megbízást, Kazuhiko, a könyvborító tervezője ezt mondta: „előbb tanulmányoznia kell a térség történelmét, fel kell kutatnia azokat a kapcsolódási pontokat és hasonlóságokat, melyek alapján könnyebben rátalál a közös nevezőre, eljuthat az emberi tényezőhöz és annak értelmezéséhez" ${ }^{11}$

A szerző vallomása szerint a felhasznált dokumentumokat át kellett alakítania: Ida naplóját tömörítenie kellett, Márta szövegét, a szúkszavúság miatt, ki kellett egészítenie más családi iratokból. A fennmaradt 1950-es önéletrajzban szúkszavúan

7 Gerlóczy: Altató. 139.

8 Wolfgang Iser: A fiktív és imaginárius. Az irodalmi antropológia ösvényei. Ford. Molnár Gábor Tamás, Osiris, Bp., 2001.

9 Umberto Eco: Hat séta a fikció erdejében. Ford. Gy. Honvátr László, Európa, Bp., 2007. 10 Uo.

11 GerLóczy: Nézd csak, itt egy japán! 10. 
megfogalmazottakat fejezeteken át kellett kibontania. „Születtem 1920-ban Nagyenyeden. Apám, Jékely Lajos (írói néven Áprily Lajos) az ottani gimnázium tanára volt. 1943-ban ment nyugdíjba, jelenleg orosz múfordításokkal is foglalkozik. Két bátyám van, mind a kettő családos. Az egyik a Nemzeti Múzeum könyvtárának tisztviselője, a másik a Földművelésügyi Minisztérium tervgazdasági osztályának előadója. 1938-ban érettségiztem. Utána négy évig a bölcsészeti egyetemre jártam, ahol magyar- latin- múvészettörténet- néprajz szakokat hallgattam. 1941-ben férjhez mentem. Férjem, Mikecs László gimnáziumi tanár volt Kolozsváron. Több néprajzi vonatkozású haladó szellemú könyve és cikke jelent meg. Foglalkozási helyét 1944ben nem hagyta el. A háborús események következtében halt meg. Nyugatra magam sem mentem s családom valamennyi tagjával lakóhelyemen maradtam. A felszabadulás után a Derkovits Kollégiumba jártam, rajzot és mintázást tanultam. 1948-49-ben a Képzőművészeti Főiskola hallgatója voltam. Ezalatt a MEFESZ-nek tagja voltam s ebben a minőségemben többirányú társadalmi munkát végeztem. Miután férjem után járó nyugdíjamat általános rendelkezés folytán megvonták, fóiskolai tanulmányaimat nem tudtam tovább folytatni. Elvégeztem egy gyors- és gépíró tanfolyamot. Gyorsírással percenként 180-200, gépírással 80 szótagszámmal írok. Értek németül és franciául. Jékely Márta Budapest, 1950. december 9."12

Dokumentaristaként, a mesét megszakítva, Gerlóczy maga is lábjegyzetben egészíti ki az egyes mellékszereplők sorsára vonatkozó adatokat. A Márta által a háború után, árva gyermekként megismert Dandos Gyula további sorsáról pár mondatban értesülünk. ${ }^{13}$ A Márta második sógorának karrierjére vonatkozó adatokat szintén lábjegyzetben olvashatjuk. A két bejegyzés a diktatúra természetére vonatkozó háttérismeretet nyújthatja azoknak is, akiknek ez nem volt személyes élettapasztalatuk. „(...) Márta arra gondol, itt az idő, megkérdezi tőle, soha nem rossz a lelkiismereted azért, hogy embereket, fiatalokat börtönbe, esetleg halálba juttattál, honnan vetted a jogot magadnak ahhoz, hogy ítélkezzél felettük, nem félsz-e attól, hogy egyszer meghasonlasz és összeroppansz. Meg szeretné kérdezni, mit csinált a Rákosi-korszakban mint ávós, milyen parancsokat volt kénytelen végrehajtani, miért nem tudják a mai napig, mi volt a beosztása." ${ }^{14}$

12 VIG Emese: Eltünt asszonyok nyomában - Gerlóczy Márton íróval beszélgettünk. Maszol. 2017. szept. 24. http://www.maszol.ro/index.php/kultura/86325-elt-nt-asszonyok-nyomaban-gerloczy-marton-iroval-beszelgettunk

13 „Élete derekán tart ezekben a napokban a kilencéves kisfiú. Később lesz forradalmár, elhurcolt rab az ungvári szovjet börtönökben, majd a megtorláskor fogoly a papíron megszüntetett ÁVH nyíregyházi vizsgálati osztályán. A forradalom leverése után vissza akar jutni Svájcba, de a határőrök a második határátlépési kísérletkor Szentgotthárdnál tizennyolc évesen és hét hónaposan agyonlövik." (GERLóczy: Altató. 28.)

14 Gerlóczy: i. m. 207. A rá vonatkozó lábjegyzet: „Mészáros Józsefet 1962 májusában nevezték ki a Hírszerző Osztály osztályvezető-helyettesévé. Eredetileg napszámos, belügyi 


\section{ANNA ÖRÖK - A NARRÁTOR}

A regényben feltáruló női sorsok egyre szúkülő mozgástere ellensúlyaként a lányutódok nagyobb szabadsága jelenik meg. Paradox módon a legszabadabb Mikecs Anna, a halott, akit már nem köt semmi társadalmi konvenció. Övé a mesélés szabadsága.

„Az egyéni és kollektív emlékezet e szövedéke meghosszabbítja az életünket, megnyújtja hátrafelé az időben, $\mathrm{s}$ a halhatatlanság ígéreteként túnik elénk." ${ }^{15} \mathrm{Az}$ időn felül/kívül álló, mégis a családhoz tartozó személy alkalmas arra, hogy a száz év történéseit elmesélhesse. Ennek a narrátornak nőnek kell lennie. A kiinduló gondolat Jékely Zoltán levelének a regény külső borítóján olvasható részlete: „Mártának üzenem, hogy bízom lelkierejében, múvészkezében, mellyel a fájdalmak szörnyú masszájából valami vigasztaló formát gyúrhat. A völgy regényét csak nő írhatja meg, utóvégre annyi női tragédiát látott már Szentgyörgypuszta, hogy bátran fel lehetne állítani az elejére a női fájdalom szobrát”. (Jékely Zoltán levele 1946-ból)

Ki láthatja és mesélheti el mindezt, III. személyű, de a történteket mégis belülről látó, női érzékenységú narrátorként? Az időn kívül álló, a családot belülről ismerô, három és fél éves korában meghalt kislány, akinek emlékére a nagyapja által írt epicedium a regény végén olvasható. „Komor napoknak fényessége volt, / hangjában tündér csengettyúje szólt. / Annának hívták. Jött egy Anna-bál, / s táncába vitte a sebes halál." (Áprily Lajos: Annának hĩuták) ${ }^{16}$

A 40 részből álló versciklus kompozíciós mintául szolgál, a regény részeinek száma követi, innen származnak az idézetek az egyes részek elején: „kis virágnak hívtak, most árnyék vagyok, kicsi árnyék”. „Vagy el se ment. Itt él a kert felett, /a Szentgyörgypuszta kistündére lett. / Ott jár a madárfészkes fák alatt, / ahol boldog volt, éber és szabad. (...) / Lát és figyel látatlanul. Miénk. / Csak nem jöhet, jaj, nem jöhet közénk.” Az árnyéklét a kötöttségek alóli felszabadulás is, tér- és időkorlátok nélküli létezés.

szolgálatát 1947-ben próbarendőrként kezdte, vidéki rendőrkapitányságokon szolgált. 1951 augusztusában került Budapestre, a BM Igazgatási Osztályán az egyesületi csoportot vezette. 1952-ben, az öt hónapos pártiskola után a BM pártbizottságának függetlenített munkatársa, 1953-tól megbízott párttitkára volt. 1954-ben a BM II. Hírszerző Osztálya állományában dolgozik. 1957 júniusában helyezték vissza a Hírszerző Osztályra, a 4. alosztály vezetője lett rendőr őrnagyi fokozattal. (...) 1962 decemberében sorosan előléptették alezredessé”. (GerLóczy: i. m. 208.)

15 Eco: i. m. 187.

16 Idézi Gerlóczy: Altató. 433-446. 


\section{A SZÉPSÉG VIGASZA}

A regény a régi Kolozsvárnak és környékének, a Szamos-parti kertnek és vakációknak idilli képével az elveszett Éden toposzát éleszti újra. A másik helyszín, a Dunakanyar, Szentgyörgypuszta a törékeny menedék, míg Brassó, Nagyenyed és Budapest a megpróbáltatások helyszínei a regény hősnői számára. Vigaszt nyújtó apróságok, megtartó részletek, a kertek, virágok, illatok, ruhák, bútorok, enteriőrök, sütemények, ízek részletes aprólékossággal megelevenített, a hétköznapok boldogságát sugárzó elemei a műnek. Gyulai Pál verse, az anyáról lányára örökül hagyott Altató visszatérő, a különböző idősíkokat és szereplőket összekötő motívum ugyanezt a megnyugtató, biedermeier hangulatot sugározza. „Aki nem sír, nem kiáltoz, / annak angyal kis kertet hoz, / lesz benne szép fa, / minden ágán aranyalma, / kis fészek meg kis madárka, / kék a lába, zöld a szárnya, / s azt énekli csengő hangon, / aludj, aludj már, galambom.” Ugyanakkor jelképessé is válik, meg ki is fordul: aki nem sír, nem kiáltoz, a 20. század asszonyai közül, éppen az nem kap, még álmában sem, Édenkertet.

A borítókészító véleménye szintén a komor tényeket ellensúlyozó szépség vigasztaló erejét emeli ki. Kazuhiko, a képet tervező japán fotómúvész így indokolja, hogy nem az író által választott családi fényképen látható kicsi árnyékot tette a borítóra, hanem az 1884 óta generációkon át anyáról lányára öröklődő, törékeny szépségű porcelán teáscsészét.

„Értem, hogy ez egy szomorú történet. Értem. Értem, hogy a nagymamádnak szomorú élete volt. Tragikus. Értem. De én kint jártam nálatok a völgyben, és láttam a családodat, és szerintem a nagymamád is látja a családodat, és látja, hogy az a sok szenvedés nem volt hiábavaló. Hogy ezt mégiscsak ő hozta létre. (...) Hiszel abban, hogy látja?

- Fogjuk rá. Mondjuk, hogy hiszem.

- Akkor szerintem hagyjuk ezt a szomorúságot, hagyjuk ezt az árnyékot, csináljunk inkább valami szépet. Neki. Tegyük boldoggá. Vidítsuk fel.”17

A fiktív narrátor halálának - immár egyes szám I. személyben elmesélt - körülményeiről az utolsó előtti részben olvashatunk, amelyet megelőz Márta első unokájának 1978-as születése. A sorrend azt érzékelteti, hogy a megrázó tény ellenére a család tovább él. Élet, álom és öröklétre szenderülés akkordjaival zárul a regény. A görög mitológiában Thanatosznak, a halál istenének ikertestvére Hüpnosz, az alvás

17 Gerlóczy: Nézd csak, itt egy japán! 61-62. 
ura. Az ő fia Morpheusz, aki akkor jelent meg a halandóknál, mikor atyja már hatalmába kerítette őket. Morpheusz az álmokban emberi alakot öltött, az álmodó szeretteinek képében jelent meg. Erre a szoros kapcsolatra figyelmeztet a befejező képsor, mely a szereplők álomba szenderülése után a halál metaforikus megjelenésével zárul. „A kis mécs a kerek székre állítva ég a szoba közepén. Ida Erzsire néz, aki a szemközti falnál lévő szép plüssdíványon alszik az ablak és az életnagyságú, aranyrámás Kossuth Lajos kép alatt. Alszik Schéfer András és Terézia a nehéz, szorosan egymás mellé állított diófa ágyaikon, alszik közöttük, behunyva nagypillájú, sötét szemét Lacika, pihen a kedves kicsi test, amelyik nappal annyit mászkált a tyúkketrecek tetején és annyit szaladgált a keményre kövezett udvaron, alszik Ernő az ebédlőben, a fekete bőrdíványon, alszik a kihúzós ágyon mellette Bandi, alszik a város és alszik Ida is. Az udvar elcsendesedik. Csak Deszka János jár az utcán. Kopog a botja a köveken, hoszszú ruhája az utat sepri, s majd' földig fityeg a batyuja."18

\section{BECAMING YOUR OWN SHADOW. SAGA IN THE 21ST CENTURY. GERLÓCZY MÁRTON: MIKECS ANNA: ALTATÓ (LULLABY)}

\section{Keywords: Márton Gerlóczy, family novel, fictitious narrator, traumas, taboos}

Márton Gerlóczy's Mikecs Anna:Altató, published in 2017, is a documentary-based family novel with a fictitious narrator, that doesn't respect the tradition of linear story telling. It presents the lives of five generations of women, whose fates are increasingly difficult. The narrator is a little girl who died at the age of three and a half, who can look beyond the time and space upon the events of her family's 100 years history. In this work on historical traumas and taboos, the gloomy facts are off set by the evocation of the beauty of details, locations, smells, tastes, clothes.

\section{TRECÂND ÎN UMBRĂ. CRONICĂ DE FAMILIE ÎN SECOLUL AL XXI-LEA GERLÓCZY MÁRTON: MIKECS ANNA: ALTATÓ (CÂNTEC DE LEAGÄN)}

Cuvinte-cheie: Márton Gerlóczy, cronică de familie, naratorfictiv, traume, tabuuri

Romanul Altató (Cântec de leagăn) de Márton Gerlóczy apărut în 2017 este o cronică de familie bazată pe documente, atribuită unui narator fictiv și care deconstruiește tehnica tradițională a narațiunii lineare. Prezintă cinci generații de femei viața cărora devine din ce în ce mai grea. Naratorul este umbra unei fetițe decedate la vârsta de trei ani jumătate care, aflându-se în afara timpului și spațiului, poate relata întâmplările unui veac întreg. Opera prezintă traumele și tabuurile din documente iar caracterul sumbru al acestora este contracarat prin evocarea frumoaselor detalii ale spațiilor, rochiilor, miresmelor și deliciilor.

18 GerLócZy: Altató. 432. 